48）為ヶ谷ほか：放送現場におけるマイクロコンピュータの利用状況, 放送技術，34，4（1981）267-275

49）釣ほか：パーソナルコンピュータの放送への利用(CPU 画像の NTSC 方式への同期方法)，放送技術，34，10（1981）865-871

50）荻野ほか：オートカラーバランス装置によるカラーバランスの自動 化及び画質の改善，民放技術報告会，17（1980） 71-72

51）宮地ほか：マイクロコンピュータ制御カラーカメラ PK-40A, 放 送技術，34，4（1981）298-303

52）安波ほか：カレイドバックカラー発生装置, 放送技術, 34, 10 (1981) 859-864

53）浦辺：マイクロコンピュータを利用したテレシネカメラの集中画質 補正システム，放送技術，34，4（1981）292-297

54）渡辺：デジタルアニメーション, テレビ学会放送現業技術研資, PPOE21-4，4, 1 (1980) 17-22

55）山田ほか：画像漢字処理システム「トスメディア」による画像文章 の作成，放送技術，34，2（1981）114-119

56）井上ほか：種字作成, 運用を容易にした文字表示装置, 放送技術, 34, 2 (1981) 120-130

57）中込ほか：ライトペンを用いた放送用グラフィックディスプレイ装 置，放送技術，34，9（1981）768-773

58）本沢ほか：テレビ送信系の自動測定システム, 民放技術報告会, 18 (1981) 105-106

59）内田ほか：野球の最高最低球速表示装置, 民放技術報告会, 17
(1980) $67-68$

60）伊藤ほか：野球スコア表示装置，民放技術報告会，18（1981）29-30

61）田端：マイクロコンピュー夕を用いたクイズ番組「THEビッグ」の 検索システム, テレビ学会放送現業技術研資, PPOE24-7, 4, 17 (1980) $37-42$

62）宇野: 報道天気情報用静止画ビデオファイル—マルチストア装 置, NHK 技研月報， 24 (1981) 99-105

63）熊倉：カメラを使わないテレビ番組「エレクトロ絵本」の制作, 放 送技術，34， 2 (1981) 107-113

64）池田：テレシネに㧍ける赤信号を利用した輪郭補正, 放送技術, 34, 3 (1981) 252-254

65）高田：テレシネカメラの色補正，テレビ誌，35，12（1981）1,004 $-1,009$

66）ランク・シンテル社：MARK III Flying Spot Telecine，商品資料， 大沢商会

67）ラング・シンテル社：TOPSY，商品資料，大沢商会

68）マグナシンク・ムビオラ社：VIDEOLA-V2000 DELUXE FILMTO-TAPE TRANSFER SYSTEM，商品資料，報映産業

69）侏與和：小型オペーク送像装置 OS-102 仕様書

70）武谷ほか：白色標準調整器, テレビ全大予（1981）73-74

\title{
2-3 録画
}

\section{正会員 羽 物 俊 秀†}

\section{1.まえがき}

この 2 年間の放送用録画機の動向を見ると, 放送用 VTR では 1 インチVTRが 2 インチVTRに代って 主役の座に着き，ENGではU マチック方式のVTR が定着した 2 年間といえる。

一方，新らしい記録技術の進歩により，数年前まで 不可能と思われていたディジタルVTRの基礎開発の 時代は過ぎようとしており，これからはディジタル信 号のスタジオ符号化規格と共に, 運用面を考慮したデ イジタルVTRの実用機を目ざして, 記録方式の規格 化の検討が重要となる。

また高品位テレビ方式用のVTRの試作や, プロ用 カメラ一体形 VTR の発表など, 最近の記録技術の高 速な進歩を改めて感じさせる 2 年間であった。

\section{2. 放送用 1 インチヘリカル VTR}

1978 年 3 月, SMPTE で規格化された1インチ・タ イプCヘリカルスキャンVTRは, 従来の 2 インチ

$\dagger$ NHK 運用技術局

“2-3 Video Recording Techniques" by Toshihide Habutsu (NHK

Technical Operation Dep., Tokyo)
4 ヘッド・トランスバース VTR に順次置き換わり使 用されてきているが，初期のVTRに比べこの 2 年間 で運用面や機能面の向上が見られる。

一例として，民放のコマーシャル一本化や深夜放送 の送出を便利にするため，3 時間（180 分）番組の記 録・再生が可能な Cタイプ VTRが発表されている (日立電子 HR-300 写真 1, ソニーBVH 1180 写 真 2)

このほかイージースレッディング機能として，片側 のガイドポストが動くVTRのほか，最近になってス レッディング時に両側のガイドポストが動くVTRが 発表された（ソニー, BVH-2000 写真 3)

また，早送りや巻きもどしのシャトルモードにおい て, ガードバンドノイズの出ない範囲を広くするた め, 自動的にトラッキングを行うためのへッドの変位 量を増やしたり (アンペックス, VTR-2 B な゙), TBC のウインドウを広くする（NEC，TT-7500 写 真 4 など）などの傾向が見られる.

一方，ヨーロッパを中心に使用されている1イン チ・タイプ BのVTRでは, 従来の1フィールドメモ リーから，2フィールドメモリーへメモリー量を増加 し，スロー時の特性の改善がなされた ${ }^{1)}$. 


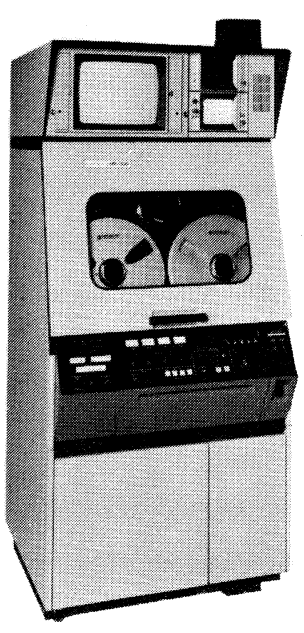

写真 13 時間 C タイプ VTR (日立, HR-300)

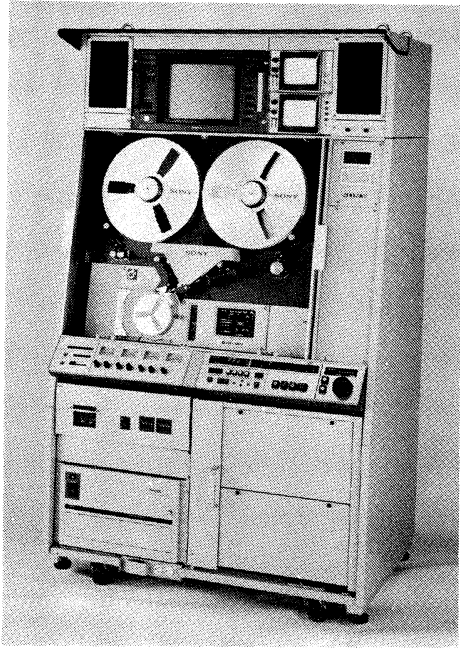

写真 23 時間 Cタイプ VTR (ソニー, BVH-1180)

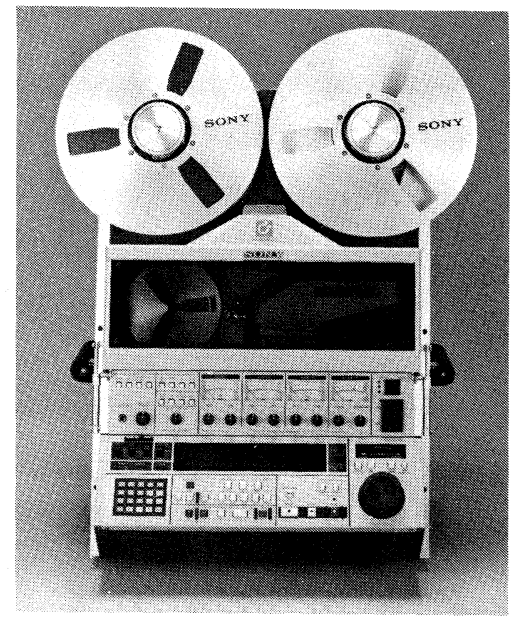

写真 3 両側のガイドポストが動くVTR (ソニー, BVH-2000)

\section{3. 放送用小形カセットVTR}

UマチックVTRの愛称で呼ばれている $3 / 4$ イン チカセットVTRは, 今や ENGの主力機器となって いるが，最近は ENGの機能をさらに発揮するよう， より高速な処理が求められている。

とくに編集機能の向上は重要な項目であり，画質の 向上とともに，アセンブルモード・インサートモード の機能改善のほか, 高速な早送り・巻もどしにおいて もカラー再生が可能な $3 / 4$ インチVTR が発表され ている (ソニーBVU-820 写真 5). また使用目的に 応じた $3 / 4$ インチ用 TBC が種々開発されている（ソ

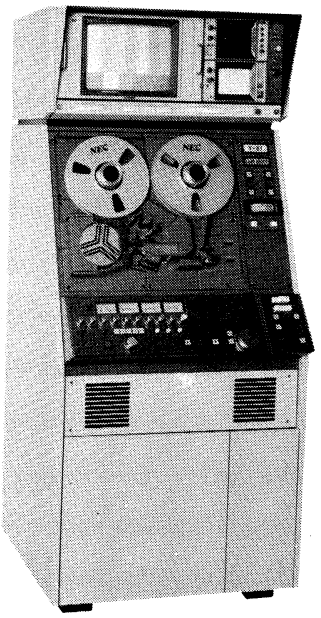

写真 4 ウインドウの広い TBC を持つVTR (NEC, TT-7500)
ニーBVT-800 など)。

一方，取材現場で使用するVTR 機器は，より小形 でより軽量で，しかも画質が良いことが要求されてい る.この目的に応じたVTRとして，1981 年 10 月の 放送機器展に参考出品されたカメラ一体形 VTR は, 今後の $\mathrm{ENG}$ を心としたVTRの方向に大きなイン パクトを与えることになろう。

松下から発表されたカメラ一体形 VTR (写真 6) は VHS カセットを使用し，ソニーから発表されたべー タカム (写真 7 ) と呼ばれる VTR はベータカセットを 用いている.いずれも標準カセットテープで 20 分の 収録が可能であり，両方式とも輝度信号用のビデオへ ッドとクロマ信号用のビデオへッドがあり， 2 チャン ネル記録・再生を行う方式である ${ }^{2) ~ 6) .2 ~ チ ャ ン ネ ル ~}$ 記録方式を採用することにより，輝度信号とクロマ信

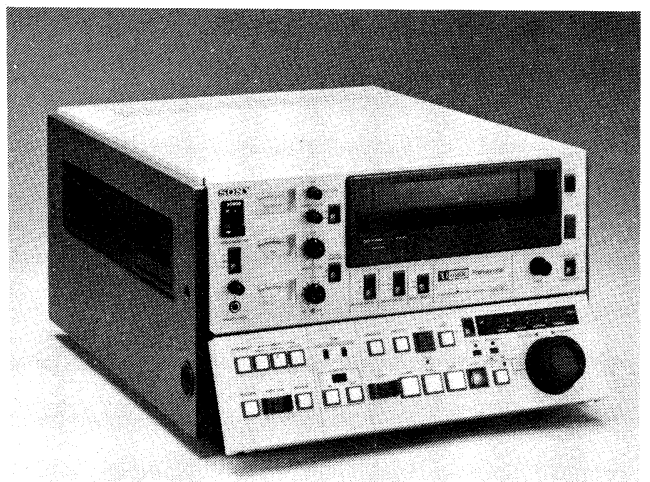

写真 5 機能が改善された $3 / 4$ インチVTR (ソニー, BVU-820) 


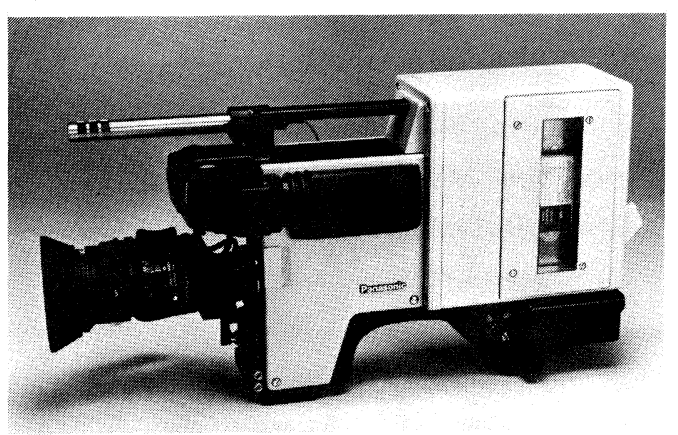

写真 6 カメラ一体形 VTR（松下電器）

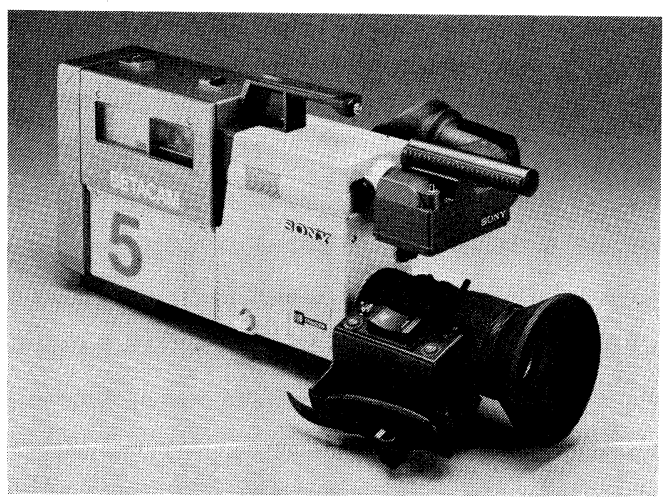

写真 7 カメラー体形 VTR (ソニー)

号の FM デビエーションを広くすることが可能で, 解像度や $S / N$ の向上が期待できる.

このほか，NHK 技研では記録時間が短いが，画質 の良いマルチチャンネル固定ヘッドVTRの実験が行 われ公開されている7.

\section{4. ディジタル VTR}

数年前まで夢であった放送用ディジタルVTRの技 術は, ここ $1 \sim 2$ 年の間に基礎研究の期間は過ぎたと 考えられ, 改めて記録技術の進歩の早さを感じさせら れる ${ }^{8) \sim 10)}$.

テレビ信号のスタジオディジタル信号規格は, SMPTEやCCIRを中心に進められているが, 次の ステップとして, 放送用ディジタル VTR の規格統一 が重要なテーマとなって来る. 現在 SMPTEのス夕 ディグループが中心となって検討を進めているが，広 く世界の互換性を保つため, スキャンニング方式, デ イジタル変調方式, 誤り検出と訂正方式などが統一さ れなければならな(11) 14).またディジタル VTRの 音声はディジ夕ルで記録することが望ましいので, 編 集を考慮した音声の記録方式も検討が進められてい $3^{15)}$.
一方，コンポーネントディジタル信号のビットレー トは，NTSC 方式と PAL・SECAM 方式でほぼ同じ となるため, 同一の機種で 525 と 625 の両方式を記 録・再生できる可能性について検討が進められてい る.

また，ディジタルVTRの小形化の研究も行われて おり，ディジタルハイアラーキーの低いビットレート 方式を採用し，テープの高抗磁力化技術との組合せ で，高画質で運用性の高いVTRの出現が期待されて (る ${ }^{16) \sim 18)}$. 次に, この 2 年間では, フロッピーディ スクを用いた映像信号のフレーム記録が目立ってい る。これはフロッピーの片面に 1 フレーム（両面で 2 フレーム)の NTSC 信号をディジタルにして記録する 方式で，高画質の信号がいつまでも記録されているた め, 試験・調整・評価などの標準信号として使用され ている.

\section{5. 高品位テレビ用 VTR（HD-VTR）}

高品位テレビシステムにおいて VTR は重要な機器 である. 1981 年にこの高品位テレビ用 VTR（HDVTR）の試作機がソニーと NHK から発表されてい る.いずれも 1 インチCタイプの機構を基本として 開発しているが，以下 NHKの方式について若干の 説明を行う。

高品位テレビ方式は毎秒 30 枚 1125 本のカラー方式 であるため, 輝度信号のビデオ帯域だけでも $20 \sim 25$ $\mathrm{MHz}$ となっている。このため, この広帯域ビデオ信 号を FM 記録するためには，従来のVTRの約 3 倍 以上の RF 帯域が必要となる. NHK 技研では磁気シ 一トによる基礎実験 (1981 年 6 月の技研公開で展示) をふまえて ${ }^{19)}$ ，現在のCタイプの機械系を使用して ヘッド・テープ相対速度を 2 倍にすることにより約 70 $\mathrm{MHz}$ の RF 帯域の記録・再生が可能となり，この結 果, 表 1 に示す方式により高品位テレビ信号の記録・

表 1 N H K 試作高品位V T R の重な諸元

\begin{tabular}{|c|c|c|}
\hline & 試作高品位TV用VTR & 現行C タイプV T R \\
\hline テープ送り速度 & $97.6 \mathrm{~cm} / \mathrm{s}$ & $24.4 \mathrm{~cm} \mathrm{~s}$ \\
\hline ドラム回転数 & $120 \mathrm{rps}$ & $60 \mathrm{rps}$ \\
\hline $\begin{array}{l}\text { ヘッド・テーープ } \\
\text { 相 対 速 度 }\end{array}$ & $51.7 \mathrm{~m} \mathrm{~s}$ & $25.6 \mathrm{~m} / \mathrm{s}$ \\
\hline 信号変調方式 & $\begin{array}{l}\text { Y C 分離 F M変調方式 } \\
\text { (クロマ信号は線順次) }\end{array}$ & $\begin{array}{l}\text { N T S C ダイレク } \\
\text { トF M変調方式 }\end{array}$ \\
\hline $\begin{array}{c}\text { 変調 周 } \text { 波 数 } \\
\text { 白ピーーク } \\
\text { ペデスタル }\end{array}$ & \begin{tabular}{|ll} 
[輝度信号) (クロマ信号] \\
約 $40 \mathrm{MHz}$ 約 $13 \mathrm{MHz}$ \\
約 $30 \mathrm{MHz}$ 約 $10 \mathrm{MHz}$ \\
\end{tabular} & $\begin{array}{r}10.0 \mathrm{MHz} \\
7.9 \mathrm{MHz}\end{array}$ \\
\hline $\begin{array}{l}\text { 映像輝度信号の } \\
\text { 帯 域 }\end{array}$ & 約 $20 \mathrm{MHz}$ 以上 & 約 $4.5 \mathrm{MHz}$ \\
\hline
\end{tabular}


再生を可能とするVTRの実験に成功した。な㧍信号 は YC 分離 2 チャンネル記録方式で, クロマ信号は線 順次記録となっている。ドラム回転数は Cタイプの 2 倍, テープ送り速度はCタイプの 4 倍となってい $3^{201211}$.

\section{6. 編集システム}

テレビの番組制作が多様化するなかで，ビデオ編集 の重要性はますます増している。編集に要求される機 能は番組制作の手法により異っているので, それぞれ のニーズに適した方式が必要となってくる ${ }^{221}$. 最近の 傾向として，マイクロコンピューターを含むインテリ ジェントターミナルを使用した機器が増加している. 一方，オフライン編集方式の重要性も増している.

オフライン編集とは, 編集に必要な情報を得るため に, 本番テープから小形カセットテープにダビングを 行って得られたテープ（ワークテープと呼ぶ）を用い て, 編集するポイントを決める方式である.このワー クテープにはタイムコードや時間スーパーがあり, 編 集者はこのテープを用いて編集を行う。このような手 段により，編集者は時間にとらわれず納得のできる編 集を行うほか, 本番テープのいたみが少くなり, 放送 用 VTRの占有時間も短縮できる.

従来のオフライン編集では, インテリジェントター ミナルとの組合せが主体であったが, ドキュメント番 組などを対象に, NHK が新しく開発した EX-1 と呼 ばれる編集情報収集方式は, インテリジェントターミ ナルを持たない簡易な編集装置でもオフライン編集が できる、編集したカセットテープを編集情報収集装置 に読込ませることにより，本番テープの編集ができる ようになっている。

小形VTRでSMPTEタイムコードを利用するた めには, 信号発生器や読取器は超小形でなければ運用 上不便である. 従来, 1 チップの発生器は開発され実 用されているが, 定率遅延回路を用いた復調法の開発 により ${ }^{23224)}$, 読取器の 1 チップ化が期待されている.

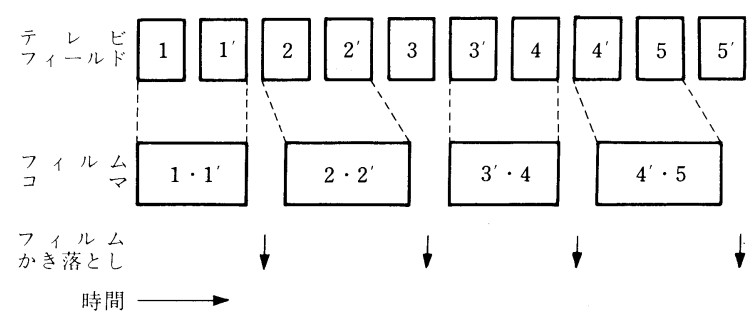

図 1 ディジタルメモリーを用いて, かき落し時間を長 くする方式
このほか，ダビング時間を短縮するため，1インチ CタイプのVTRから $3 / 4$ インチVTR , 通常の 5 倍速でダビングを行う機器も開発されている ${ }^{25}$.

\section{7. フィルム録画}

従来のフィルム録画は $16 \mathrm{~mm}$ フィルムに記録する 方式で，テレビ信号の垂直帰線期間にプルダウンを行 う，いわゆるミリケン方式が主体であったが，最近， 高画質のフィルムが要求されるようになり， $35 \mathrm{~mm}$ フィルム録画ではこのミリケン方式が使用できない. テレダイン社が開発した方式は，フィルムのかき落し 時間を長くするためにディジタルメモリーを用いてい る $(\text { 図 } 1)^{26)}$.

一方，フィルム録画の画質向上のためにレーザーを 用いた録画方式は ${ }^{27)}$ ，基礎開発が完了し，実用の段階 に入っている。

フィルム録画の画質向上により，テレビカメラや VTRのいっそうの画質向上が新らしく要求されて来 ている.

\section{8.むす び}

上記のほか VTR 関係の測定器の進歩や28), 将来有 望視されている高抗磁力テープの進歩 ${ }^{29301}$ が発表され ており，記録技術は今後も早いテンポで進歩すると思 われる。一方, 記録機器で重要な規格の作業も SMPTEやIECを中心に進められており ${ }^{31}$, 我が国 の技術が世界をりードして行くことが期待されてい る.

終りに，資料を提供して下さった方々に，深く感謝 します。

(昭和 57 年 3 月 23 日受付)

\section{〔参 考 文 献]}

1）相馬喜三：BフォーマットVTRとその応用, テレビ誌, 35, 8 (1981)

2）中村好郎ほか：超小型化映像技術と録画カメラの展望，放送技術， 34, 10 (1981)

3）高野昌幸ほか：ビデオカメラの規格および諸特性，放送技術，34， 10 (1981)

4）野谷正明：ENG 用カメラ一体型 VTRの概要，放送技術，34, 10 (1981)

5）高野昌幸ほか：ENG 用カメラ一体型 VTR，テレビ学会録画研資， VR 48-3 (1981)

6）野谷正明：ENG 用カメラ一体型 VTRの概要，テレビ学会録画研 資, VR 48-4（1981）

7）角井良治ほか：放送用超小形 VTR 実験機の試作，テレビ学会録画 研資 $(1980.9)$

8）ディジタルVTR 特集号, テレビ誌，35，7（1981）

9) 橋本慶隆: 今後期待されるディジタル機器——゙ィジタル VTR, テレビ誌, 36, 1 (1982)

10) Y. Eto, et al : Experimental Digital VTR with Trilevel Record ing and Fire Code Error Correction, SMPTE J., 90, 7(1981)

11）稲垣カッヒコ:ディジタルVTRのフォーマット, テレビ学会録画 研資 $(1980.12)$ 
12）中川省三：ディジタルVTRとその実用化に向けての問題点, NHK 技研月報，25，2（1982）

13）林和夫：第 12 回モントルー国際テレビジョンシンポジウムに出席 して，テレビ誌，35，10(1981)

14) Y. Hashimoto, et al : Digital Component Video Recording at 230 Mbit/sec, SMPTE J., 90, 10 (1981)

15）村松珊吾：ディジタルVTRの関連を考虑した時の音声標本化周波 数，テレビ学会放送現業技術研資，PPOE 31-1（1981）

16）吉岡浩ほか：28.6 Mbps 信号のディジタル磁気録画実験報告，テ レビ学会録画研資 $(1980.12)$

17）高橋孝夫ほか：低ビットレートディジタルVTRの赛験，テレビ 誌，35， 7 (1981)

18）大島英男ほか：放送用小型ディジタルVTRの方式検討，テレビ学 会録画研資，VR 48-1 (1981)

19）高品位磁気録画の基礎実験，NHK 技研公開資料（1981）

20）柴谷弘道ほか：高品位テレビジョン機器の開発の現状- VTR, NHK 技研月報, $24,11 / 12$ (1981)

21）柴谷弘道ほか：高品位テレビ用VTRの開発，テレビ学会録画研
資, VR 48-2（1981）

22）小川武：ビデオ編集技術，兼六館出版（1981）

23）関口卓二：VTR 編集用夕イムコードの新らしい復調法, NHK 技 研月報，24，10（1981）

24）関口卓三：定率遅延回路によるVTR 編集用夕イムコードの簡易復 調法，テレビ誌，35，6 (1981)

25）花井一郎ほか：VTR 高速ダビング装置，テレビ学会録画研資 (1980.6)

26）佐藤貞二郎：テレダイン社 $35 \mathrm{~m} / \mathrm{m}$ キネコーダー, テレビ学会光 フィルム技術研資 $(1981.3)$

27）元木紀雄：RGB 信号のレーザー録画，テレビ学会光フィルム技術 研資 $(1980.6)$

28）深瀬賢四郎：VTR 自動計測装置，テレビ誌，35，12（1981）

29）北本達治：高密度ビデオテープ，テレビ誌，35，9（1981)

30）蓬郷章郎：ビデオ用蒸着テープ, テレビ誌，35，9 (1981)

31）羽物俊秀：IEC TC $60 \mathrm{SC} 60 \mathrm{~B}$ に出席して, テレビ誌, 35,6 (1981)

\section{2-4 伝 送 中 継}

正会員 片 山修 二十, 正会員 村上 仁 $己^{+\dagger}$

\section{1. まえがき}

我が国のテレビ中継業務は国内を日本電信電話公社 （電電公社）が，国際を国際電信電話株式会社（KDD） がそれぞれ分担している。

国内のテレビ中継網は昭和 29 年に東京〜大阪間に $4 \mathrm{GHz}$ 帯を用いた中継線を開通して以来，年々拡大 され, 今や全国の中継延距離は 9 万 $\mathrm{km}$ に達しょうと している.

この間，カラー化，映像音声同時伝送方式の導入， 年々増大する番組プログラムの切替作業を機械化する ためのテレビ回線制御方式 (MASCOT) の導入，音声 多重中継の実施等が図られた。

さらに，テレビが国民生活に深くとけ込んでいる今 日，テレビ中継網の障害が社会へ与える影響の大きさ ははかり知れないものがあり，中継網の信頼性を向上 させるため $4 \mathrm{GHz}$ 可搬形無線装置，テレビ回線モニ ター方式の導入等が図られた ${ }^{122}$. これらについては, すでに本誌（1974 年 7 月号，1976 年 7 月号，1980 年 7 月号）で紹介されている.

$\dagger$ 日本電信電話公社 技術局

门† 国際電信電話株式会社 研究所

"2-4 Domestic and International Transmission" by Shuji Katayama (Nippon Telegraph and Telephone Public Inc., Tokyo) and Hitomi Murakami (Kokusai Denshin Denwa Company, Ltd., Tokyo)
ここでは，テレビ中継に関する最近のトピックスと して，全固体化されたマイクロ波中継装置，災害対策 用の可搬形テレビ切替装置および小形軽量化された $11 \mathrm{GHz}$ 可搬形テレビ中継装置について紹介する.

国際テレビ伝送の需要はここ数年大幅に伸びてい る、インテルサットでは大西洋地域, インド洋地域, 太平洋地域とも 1 トランスポンダー当り 2 チャンネル の伝送（ハーフトランスポンダー伝送）を導入し需要 の急増に対応している。さらに映像信号と音声信号を 同一チャンネルで伝送する方式（FM サブキャリア方 式）に切り換え，衛星全体の伝送容量の増大を図って いる.ここでは, 最近の国際テレビ中継トラフィック の伸びの様子と，上記 FM サブキャリア方式につい て簡単に紹介する。さらに最近開催された CCIR 会合 でのディジタルテレビ高能率符号化の研究動向につい て述べる。

\section{2. 全固体化されたマイクロ波中継装置 $(\text { SF-B7 方式 })^{3)}$}

現在, 国内のテレビ中継網は進行波管を除き固体電 子化された SF-B5 方式を主体に構成されている. SF -B7 方式は進行波管に代る高出力のマイクロ波トラン ジスタ（段付き電極トランジスタ：SET*）を採用する ことにより全固体電子化を図り, SF-B5 方式に比較 